the ruling, claiming that "school boards can now resist pressure to include creationism in science classes". Indeed, as a result of the Little Rock decision, a school board in Tacoma, Washington, last week stopped requiring the teaching of creationism in biology classes.

However, the dispute is not going to wither away and the next major test will come later this year in Louisiana, which also passed a law requiring equal treatment for creation science and evolution in its public schools last year. Ms Martha Kegel, the executive director for the state's ACLU chapter which is mounting a comparable challenge to that raised in Arkansas, said last week that she was "elated" not only by Judge Overton's verdict, but by the detailed critique of creation science that he had developed on the basis of the testimony delivered during the Little Rock trial.

Yet the Louisiana case is far from clearcut. In the first place, the local judge is under no legal obligation to take Judge Overton's verdict into account, since it is a separate jurisdiction.

Second, the Louisiana bill omits some of the detailed provisions of the Arkansas law, for example its stipulation that creation science must include the notion that the Universe, energy and life were created "from nothing", a requirement which several religious witnesses said clearly implied the necessary existence of a creator. ACLU claims that this change only exacerbates the extent to which the bill is unconstitutionally vague; the creationists hope that this revision will remove the basis for some of the strongest objections.

Third, leading members of the creationist movement are likely to take a much more active role in the prosecution of the Louisiana case than they were permitted to do in Little Rock.

Meanwhile in Arkansas the state attorney general has yet to decide whether to implement his previous promise that he would appeal against the verdict if it went against him. And in ACLU, contingency plans are being discussed for Mississippi, in case it is decided that the law should be contested there as well. David Dickson

\section{University of London}

\section{Separatists emerge}

The University of London, parts of which already live with the threat of bankruptcy, now faces balkanization as well. Last week, University College, the largest multidisciplinary college in the university (with 6,000 students) formally asked that it should in future be dealt with financially as if it were an independent university, with its own grant allocation from the University Grants Committee.

The demand is more like gauntlet thrown down before the university's management than a unilateral declaration of independence. Sir James Lighthill, Provost of
University College, nevertheless says that the college would continue to play a full part in the university even if, like Imperial College, it were directly financed.

Especially since last summer's delayed allocation of funds to the London colleges by the court of the university, University College has been a fierce critic of the court's procedures. Last year, Sir James Lighthill won acceptance of the principle that a college's success in obtaining research grants should count - in its favour - in the annual distribution. The precedent for his latest move is Imperial College, which has been directly financed for the past two decades.

The problem now facing the university court, the ultimate authority which shares out funds among the colleges, is tricky. It is certain to regard financial independence for University College as a dangerous precedent. But the court must also be conscious that with the impending retirement of the principal (its chief of ficer), $\mathrm{Mr}$ J. R. Stewart, together with some of his more experienced colleagues, its ability to administer its funds intelligibly may be further impaired.

Discontent about the court's procedures has been simmering since the summer, when the court translated the grants committee's targets for 1983-84 into financial allocations for the present academic year and target student numbers for two years ahead. One difficulty for the colleges is that they are required to adjust to reduced budgets without knowing whether their individual plans for the future will add up to what the grants committee expects of the university as a whole. This gap will be bridged only after the publication (expected next week) of the reports of the committees set up in September to consider the balance of teaching in broad subject areas.

Meanwhile, the non-medical parts of the university have made little headway with reorganization. The announced bethrothal of King's College and Bedford College has not led to marriage but to an agreement to associate. The plan for an association between Queen Elizabeth College (the smallest in the university) and Imperial College has been put on ice, partly because Queen Elizabeth College could not accept that the association should be contingent on conditions, such as the provision of new buildings, that could not be satisfied for some time to come.

The late starters have on the whole done best. Chelsea College, faced with starkly reduced numbers and the continuing cost of buying its new site, began the academic year with a draconian plan which entailed the elimination of whole departments, and is now in a position to make substantial economies while softening its plan. And Royal Holloway College, blessed with a huge site 20 miles from central London, is being reluctantly courted by various suitors hopeful that they may be able to turn their city sites into handsome dowries.
Academic censorship

\section{Shadow ahead}

\section{Washington}

Admiral Bobby Inman, deputy director of the US Central Intelligence Agency, last week dismissed as "somewhat disingenuous" the blanket claims of scientists to scientific freedom in the light of arrangements routinely made with private, corporate sources of funding, and said that the overlap between technical information and national security "inevitably produces tension"'.

Admiral Inman, who as head of the National Security Agency under the Carter Administration started a dialogue with the scientific community over how to handle potentially sensitive but unclassified research in cryptography, also urged cooperation between scientists and security agencies to find a mutually acceptable relationship "before significant harm does occur which could well prompt the federal government to overreact'. He suggested that a potential balance between national security and science "may lie in an agreement to include in the peer review process (prior to the start of research and prior to publication) the question of potential harm to the nation'".

The admiral's remarks, delivered to a session forming part of the annual meeting of the American Association for the Advancement of Science (AAAS) in Washington, provoked a strong protest from some of the scientists present.

Professor Peter Denning, for example, professor of computing at Purdue University and president of the Association for Computing Machinery, claimed that efforts to restrict the publication of technical research data reflected a growing protectionist mood in the government which would stifle scientific communication and ultimately prove destructive to the growth of new technologies.

Responding to such concerns, the board of directors of the AAAS later passed unanimously a resolution opposing government restrictions on the dissemination, exchange or availability of unclassified knowledge. Others who took part in the AAAS session, however, accepted that the issue was not clear cut, and that many of the government's concerns were legitimate - even if they had occasionally been executed over-zealously, or had had their legal ambiguity exploited in the past.

Dr Mary Cheh, for example, professor of law at George Washington University, said in a paper on the government control of private ideas that the real question was not whether the government was justified in imposing secrecy on scientific research, but how far its efforts should be permitted to go.

Similarly, Congressman Paul McCloskey presented a paper, read in his absence, describing his legislative efforts to introduce a new bill aimed at clearing up 